\title{
Civitas \\ Revista de Ciências Sociais
}

Volume 2, número 2, dezembro 2002

\section{Democracia, mídia e cultura política}

Flavio E. Silveira

Organizador 



\section{Sumário}

Apresentação

Democracia, mídia e cultura política.

Flávio Eduardo Silveira

Os ojetivos dos partidos sob regimes autoritários

eleitorais ou democracias frágeis.

Jogo em duas frentes.

Scott Mainwaring

Abordagens ao aprendizado político.

Paulo J. Krischke

Situando o pós-modernismo na perspectiva do

desenvolvimento moral-cognitivo.

Stephen Chilton

Racionalidade ética como fundamento de uma

sociedade viável.

Reflexões sobre suas condições de possibilidade desde a crítica filosófica do fenômeno da "corrupção"

Ricardo Timm de Souza

Propaganda política e a construção da imagem

partidária no Brasil

Afonso de Albuquerque e Marcia Ribeiro Dias

Visibilidades e estratégias nas eleições presidenciais de 2002 no

Brasil Política, mídia e cultura

Antonio Albino Canelas Rubim

Pesquisas, enquetes e estudos eleitorais.

Flavio Eduardo Silveira 



\section{Apresentação}

\section{Democracia, mídia e cultura política}

A revista Civitas convida, neste número, à reflexão sobre temas políticos de grande relevância na atualidade. O problema da democracia, tema clássico do pensamento político, mantém-se no centro do debate contemporâneo quando se analisam os processos de transição dos regimes autoritários para os regimes democráticos, os elementos fomentadores de democracia, os valores e a cultura política que estimulam a conquista e manutenção de regimes democráticos e as novas características da democracia na era midiática.

Os temas democracia e mídia encontram-se fortemente associados. A grande expansão da mídia eletrônica e o seu papel chave nos processos eleitorais, como meio de veiculação da propaganda dos partidos e candidatos e dos debates eleitorais e como agente realizador da cobertura dos acontecimentos da campanha eleitoral, provocaram alterações consideráveis nas características dos regimes democráticos. A relação entre candidato e eleitor tornou-se mais direta, dispensando, em parte, a intermediação dos partidos políticos. Desenvolveram-se as tendências à personalização do voto e à valorização de elementos simbólicos relativos à imagem dos candidatos e partidos.

O enfraquecimento da crença nos partidos e o papel crescentemente relevante exercido pela mídia nos processos eleitorais estimularam o debate sobre a influência dos meios de comunicação sobre as escolhas dos eleitores, seja como agente formador de opinião, ou como agente que estabelece os temas da agenda política, ou ainda como agente que fornece as formas percepção e de enquadramento dos acontecimentos políticos. Este debate foi feito, conjuntamente à discussão acerca da influência das pesquisas eleitorais sobre a decisão do voto. 
Neste contexto, os temas relativos à cultura política foram valorizados. Isto se deve, de um lado, aos receios de que o enfraquecimento da democracia centrada em partidos poderia significar o enfraquecimento dos regimes democráticos existentes. O suposto de que a sustentação de um regime democrático depende da existência de uma cultura política amplamente aceita e fortemente apoiada em valores democráticos estimulou estudos sobre o assunto. De outro lado, a realização de surveys sobre temas políticos por institutos de pesquisa e por pesquisadores na área acadêmica possibilitou maior compreensão dos elementos valorativos e simbólicos constituintes dos referenciais dos eleitores. As pesquisas realizadas permitiram a identificação de valores indicativos, seja da descrença na democracia, observada especialmente nos países latino-americanos e, entre eles no Brasil, ou das tendências comportamentais que sugerem a emergência de um novo modelo de democracia.

Os textos reunidos neste número de Civitas abordam aspectos particulares da temática geral democracia, mídia e cultura política. Os trabalhos podem ser, grosso modo, divididos em dois grupos. O primeiro aborda de forma mais direta problemas relacionados com democracia e cultura política.

Scott Mainwaring analisa o problema da democracia a partir do jogo político e eleitoral. Estuda o comportamento dos partidos políticos em eleições competitivas sob regimes autoritários e em democracias frágeis, tendo por referência o processo de democratização iniciado em países latinoamericanos em 1978. O foco da análise é direcionado às estratégias utilizadas pelos partidos, tendo em vista os objetivos de conquistar votos no jogo eleitoral e de influenciar o processo de disputa sobre a mudança do regime político.

Paulo Krischke aborda o problema do aprendizado político, como fonte relevante para a conquista e o aperfeiçoamento da democracia. Examina os modelos explicativos sobre o aprendizado político, indicando as limitações da teoria das elites e da teoria da modernização e as contribuições do pensamento de Habermas ao estudo da problemática. Com base nestes referenciais, analisa as mudanças de valores que caracterizam o processo de democratização, tendo por base resultados de estudo comparativo da cultura política em Porto Alegre e Curitiba.

O pensamento de Habermas também constitui referência importante para a argumentação desenvolvida por Stephen Chilton sobre elementos fundamentais da cultura política contemporânea. O conceito de "ciência reconstrutiva" de Habermas é utilizado para a reflexão sobre o problema da pós-modernidade e do desenvolvimento moral e cognitivo. A cultura pós- 
moderna, do mesmo modo como os elementos morais e as formas de percepção predominantes, são traços essenciais das características do novo modelo de democracia que está se constituindo na atualidade.

$\mathrm{O}$ artigo de Ricardo Timm de Souza aborda um problema extremamente importante para a democracia contemporânea: o problema da corrupção. A descrença nos valores democráticos está fortemente associada aos problemas de natureza moral, entre os quais destaca-se a corrupção. $\mathrm{O}$ autor reflete sobre o fenômeno da corrupção, através de um trabalho analíticodesconstrutivo, desenvolvendo, em um segundo momento uma argumentação propositiva, voltada às condições de possibilidade da instauração de uma sociedade democrática baseada na ética da alteridade.

O segundo conjunto de textos refere-se mais diretamente aos problemas da mídia, das eleições e da cultura política. Existem várias pontos de contato entre os assuntos tratados pelos artigos deste grupo e aqueles anteriormente mencionados.

Os problemas da democracia e do papel dos partidos políticos e da mídia na atualidade são discutido pelo trabalho de Afonso de Albuquerque e Márcia Ribeiro Dias. Os autores questionam a tendência de personalização do voto, crescimento da decisão eleitoral em função da imagem dos candidatos e enfraquecimento dos partidos. Seu argumento principal refere-se ao caso brasileiro e encontra-se na legislação que regula a propaganda política na televisão. As regras do jogo imputam aos dirigentes partidários o poder de determinar quais candidatos terão acesso à televisão e qual tempo será destinado a cada um deles. Os partidos podem estabelecer estratégias de ocupação do espaço midiático.

Albino Rubim também aborda o problema da mídia, mas o seu foco principal é o processo eleitoral. A análise refere-se à intensa visibilidade midiática das eleições presidenciais de 2002, traço distintivo deste processo eleitoral em relação à experiência das eleições presidenciais de 1998 . O trabalho examina as estratégias de campanha dos principais candidatos (Luís Inácio Lula da Silva e José Serra) e as formas de construção e descontrução de imagens que caracterizam as disputas eleitorais contemporâneas.

$\mathrm{O}$ artigo de minha autoria aborda os temas democracia, partidos políticos, mídia, eleições e cultura política de forma indireta, através do exame da produção intelectual brasileira sobre estes assuntos. Fornece uma visão panorâmica dos estudos eleitorais desenvolvidos na área acadêmica desde os anos 40, em uma parte do trabalho. Em outra parte, a análise volta-se às experiências de pesquisas eleitorais produzidas pelos institutos e considera os problemas da credibilidade dos institutos, da influência exercida pelas pesquisas e das possibilidades de erro em pesquisa eleitoral. 
Flavio Eduardo Silveira 